\title{
Modelling Economic Growth Based on Economic Freedom and Social Progress
}

\author{
Laura Asandului ${ }^{1}$, Andreea Iacobuta ${ }^{2}$, Cristina Cautisanu ${ }^{3}$
}

\begin{abstract}
Economic growth is one of the most widely studied issues in the specialised literature. Economic growth highlights those changes that occur in enhancing macroeconomic results that are not expressed independently, but in close connection with its determinants. This article aims at modelling the economic growth of the member states of the European Union in relation to the economic freedom index and the index of economic progress.

We consider the following objectives: the study of the intensity of relationships between GDP per capita and index of economic freedom on one hand, and social progress index on the other; modelling growth relative index of economic freedom and social progress index for the EU Member States Union. To investigate these topics, we have used descriptive analysis, analysis of variance, correlation analysis, and multiple regression analysis.

We have developed a multiple regression model to study the influence that the index of economic freedom and of the social progress index have on the growth rate of GDP per capita in countries which have the status of member the European Union. Through variance analysis, we have concluded that there are significant differences among the average GDP per capita in the European countries according the membership of the European Union.
\end{abstract}

Keywords: modelling economic growth, economic freedom, social progress, european countries

\section{Introduction}

In liberal tradition, since Adam Smith, economic freedom has proven to be the best path to prosperity. It is the key issue for all countries, but in order to consider it a progress it has to be accompanied by a general social and spiritual progress. Economic growth stands for the real increase, in a certain period of time and within a certain space, of an aggregate economic indicator such as GDP.

Economic growth highlights those changes occurring in the increase of the macroeconomic results expressed not independently, but in close connection with its determinants. A wide range of both theoretical and empirical studies points out to a great variety of determinants of this process: investment, accumulation of physical capital, human capital, innovation, geography, political and legal institutions, macroeconomic conditions etc. are all considered to play a role in enhancing economic performance (Bassanini and Scarpetta, 2001; Petrakos and Arvanitidis, 2008; Moral-Benito, 2009).

Out of the numerous explanatory variables presented in literature as determinants of economic growth, our paper considers economic freedom and social progress.

Knowing the economic environment of a country requires knowledge of the degree of freedom of the respective economy. The higher the degree of economic freedom, the

\footnotetext{
${ }^{1}$ Professor at "AlexandruIoanCuza" University, Faculty of Economics and Business Administration,

Department of Accounting, Applied Computing Science and Statistics.

${ }^{2}$ Associate Professor at "AlexandruIoanCuza" University of Iasi, Romania, Faculty of Economics and Business Administration, Department of Economics and International Relations.

${ }^{3} \mathrm{PhD}$ student at "Alexandru Ioan Cuza" University, Romania.
} 
more successfully a company can implement any strategy and marketing policy in that market (Muşetescu, 2012).

There have been many attempts to quantify the degree of economic freedom. A heterogeneous range of indicators which aim at quantifying economic freedom has been developed (for example, Economic Freedom of the World from Fraser Institute, Index of Economic Freedom released by Heritage Foundation \& Wall Street Journal, World Survey of Economic Freedom from Freedom House). They share several similarities since most of them include in their methodology the core elements of economic freedom: secure private property rights, rule of law, freedom of trade, limited government (Iacobuță and Gagea, 2010).

In this paper economic freedom is analysed using the Index of Economic Freedom from Heritage Foundation \& Wall Street Journal. It is an aggregate indicator, determined as the mean of the scores for each of its 10 components. The components of the indicator are grouped into 4 categories, namely Rule of law, Limited government, Regulatory efficiency and Open markets (Heritage Foundation, 2016). According to the index methodology, for each of the 10 components, a country receives a score which ranges from 0 to 100. The higher the score is, the higher the degree of freedom included in that component.

Social progress is the ability of a society to meet the basic human needs of its members, to create institutions that enable individuals and communities to increase and maintain their quality of life and create favourable conditions for individuals to be able to reach their full potential. Social progress is measured by Social Progress Index released by Social Progress Imperative. It is calculated as the mean of the scores for three dimensions: Basic Human Needs, Foundations of Wellbeing and Opportunity. Each of these dimensions is disaggregated into components which capture the multifaceted concept of social progress (Social Progress Imperative, 2013). Thus, the first dimension captures, in four components (Nutrition and basic medical care, Air, water, and sanitation, Shelter and Personal safety), the degree to which the most essential conditions for survival are met. The Foundations of Wellbeing dimension consists of four components which measure whether citizens have access to basic education, can access information both within the country and outside, and if they have conditions that ensure a healthy life. This area also takes into consideration the protection of the environment. The third dimension - Opportunity - is also divided into four components (Personal rights, Access to higher education, Personal freedom and choice and Equity and inclusion) which capture citizens' rights and freedoms and their ability to act according to their own decisions. Also, the components indicate if the existing prejudices or hostilities forbid individuals to achieve their potential. This dimension also assesses the accessibility to advanced forms of education which highlights the potential of individuals in a society. All the scores - for the aggregated index, for the three dimensions and for the components - are based on a scale from 0 to 100 . This scale is determined by identifying the best and the worst absolute performance, at global level, for each indicator recorded for each country from 2004 until present. These levels of performance are used to set the maximum (100) and the minimum (0).

The purpose of this article is to model economic growth in relation to the index of economic freedom and the social progress index at the level of the EU member states. 
Its objectives are: studying the intensity of the relationships between GDP per capita, index of economic freedom and social progress index and modelling economic growth (measured by growth rates of GDP per capita) in relation to the index of economic freedom and social progress index at the level of EU member states.

To achieve these objectives, the following methods were used: descriptive analysis, analysis of variance (ANOVA), correlation analysis and multiple regression.

This paper continues as follows: the next section provides a review of the literature on the subject. Section 3 focuses on data and methods used in our analysis. The research results are presented in Section 4. The last section summarizes the conclusions of this research.

\section{Literature Review}

The importance of the subject finds its coverage in numerous studies on the impact economic freedom or social progress has on economic growth. The literature proves the existence of significant relations between economic freedom (or its components) and economic growth. Barro (1997) provides empirical proofs that free markets and property rights support economic growth. The empirical study of Gwartney, Lawson and Holcombe (1999) examines the importance of economic freedom in four areas namely money and inflation, economic structure, takings and discriminatory taxation and international trade. Their results indicate that economic freedom is a "significant determinant of economic growth, even when human and physical capital and demographics are taken into account" (Gwartney, Lawson and Holcombe, 1999, 643). Carlsson and Lundstrom (2001) argue in favour of a strong positive relation between economic freedom and economic growth. Baumol (2002) shows that, in those societies with strong rule of law, the freedom of economic system is a key element for economic growth.

The study by Engle (2006) on several European countries, aiming at analysing the correlations between the components of economic freedom and growth points out that monetary freedom, labour freedom, property rights and freedom from corruption are strongly correlated with economic growth.

Feldman (2007) proves that economic freedom is likely to reduce unemployment. Bjornskov and Foss (2008) used Fraser Institute Economic Freedom Index to explain cross-country differences in the level of entrepreneurship (a core element of a market economy) and found out that the size of government is negatively correlated and sound money is positively correlated with entrepreneurial activity.

Farr, Lord and Wolfenbarger (2008) analysed the causality between economic freedom and growth on a sample of 98 countries and their results show that economic freedom Granger-causes economic growth. Faria and Montesinos (2009) found a "robust association between economic freedom and prosperity". In their literature review on this subject using the Economic Freedom of the World index, Hall and Lawson (2014) indicate that over two-thirds of the existing studies found that economic freedom is related to positive outcomes such as faster growth, better living standards, and more happiness.

When examining the economic freedom and economic growth nexus in a panel of 28 
EU countries, Kacprzyk (2016) finds a positive relationship between economic growth and security of property rights, quality of monetary policy, freedom to trade and regulatory policies.

The existing literature also deals with the relation between social progress and economic growth. Researchers at Deloitte conducted a report analysing the relationship between GDP and social progress. Thus, they concluded that there is a significant correlation between the two variables. They argue this correlation by the fact that states which have a high level of income have more resources to meet the needs of individuals. However, the data reveals significant differences between social progress and economic development in terms of income: economic development does not entirely explain social progress (Social Progress Imperative, 2013).

In another report done by researchers at Deloitte, there was analysed, among other issues, the connection between two components of social progress index (ecosystem sustainability and health and wellness) and GDP. The researchers identified a complex relationship between these variables. This link is explained by the fact that each of the components embeds elements showing a positive correlation with GDP and but also items that do not relate or show a negative relation with GDP (Social Progress Imperative, 2015).

\section{Data and Methods}

The database includes variables concerning 40 European countries. We considered the following variables: the European Region the state is a part of ("Eastern Europe", "Western Europe", "Northern Europe", and "South of Europe"), membership of the European Union ("Yes", "No"), GDP per inhabitant (2014), GDP per inhabitant (2013), Index of Economic Freedom, Index of Social Progress, and rate of growth of GDP per inhabitant. The sources of data are WorldBank, Heritage Organization, and Social Progress Imperative.

Variance analysis is a statistical method that can be used to analyze the variable variation in relation to influencing factors. ANOVA consists of total variance decomposition of a set of data in source components variance (causes) and comparing them to determine whether those factors were significantly influencedthe variable. In order to to see if variable Membership of the European Union affects GDP per capita we used ANOVA. Correlation analysis was used for the study of the intensity of the relationship between the economic freedom index and GDP per capita, and between economic freedom index and index of social progress. With the aim of modelling the economic growth on the base on economic freedom index and index of social progress for European countries a multiple regression model was used. This method shows the intensity of the relationship between the factors being considered and their influence on the studied phenomenon. To validate the econometric model, we verified the fulfillment of assumptions both in the deterministic component and in the stochastic component. Stochastic component checks the following assumptions: the influence of the error term in the series is null, the hypothesis of homoscedasticity, the hypothesis of independence, and the hypothesis of normality. To validate the deterministic term, we validated the collinearity hypothesis of the independent variables. 


\section{Results}

In Table 1 are summarized the main indicators of central tendency, dispersion and shape for the distributions of the variables analyzed.

Table 1. Descriptive analysis for "GDP per capita", "Index of Economic Freedom" and "Index of Social Progress"

\begin{tabular}{|c|c|c|c|}
\hline & GDP per inhabitant (2014) & Index of Economic Freedom & Index of Social Progress \\
\hline Valid & 40 & 40 & 40 \\
\hline Missing & 0 & 0 & 0 \\
\hline Mean & 26907.280 & 66.542 & 75.766 \\
\hline Median & 19015.495 & 67.100 & 77.080 \\
\hline Mode & $2238.9^{a}$ & $63.5^{\mathrm{a}}$ & 86.6 \\
\hline Std. Deviation & 23519.7674 & 7.1287 & 8.5202 \\
\hline Variance & 553179456.859 & 50.818 & 72.593 \\
\hline Skewness & 1.197 & -.779 & -.203 \\
\hline $\begin{array}{l}\text { Std. Error of } \\
\text { Skewness }\end{array}$ & .374 & .374 & .374 \\
\hline Kurtosis & 1.038 & .053 & -1.270 \\
\hline $\begin{array}{l}\text { Std. Error of } \\
\text { Kurtosis }\end{array}$ & .733 & .733 & .733 \\
\hline Minimum & 2238.9 & 49.3 & 60.1 \\
\hline Maximum & 97307.4 & 76.2 & 88.1 \\
\hline Sum & 1076291.2 & 2661.7 & 3030.7 \\
\hline
\end{tabular}

a. Multiple modes exist. The smallest value is shown

The average value of the GDP per capita is equal to 26,907.280 US dollars and standard deviation is 23519,7674 US dollars. The small difference between the two values indicate a lower degree of homogeneity of the distribution. The coefficient of variation of $87.41 \%$ indicates a high degree of heterogeneity of the distribution.

The Index of economic freedom and social progress index have homogeneous distributions. Variation coefficient values for each of these indices $(10.71 \%$ for the index of economic freedom and $11.24 \%$ for the social progress index, respectively) shows that the distributions shows a high degree of homogeneity and the mean has a high degree of representativeness.

The distribution of countries analyzed, depending on variables Region and Freedom index, is shown in Table 2.

Table 2. The European Region * Index of Economic Freedom Crosstabulation

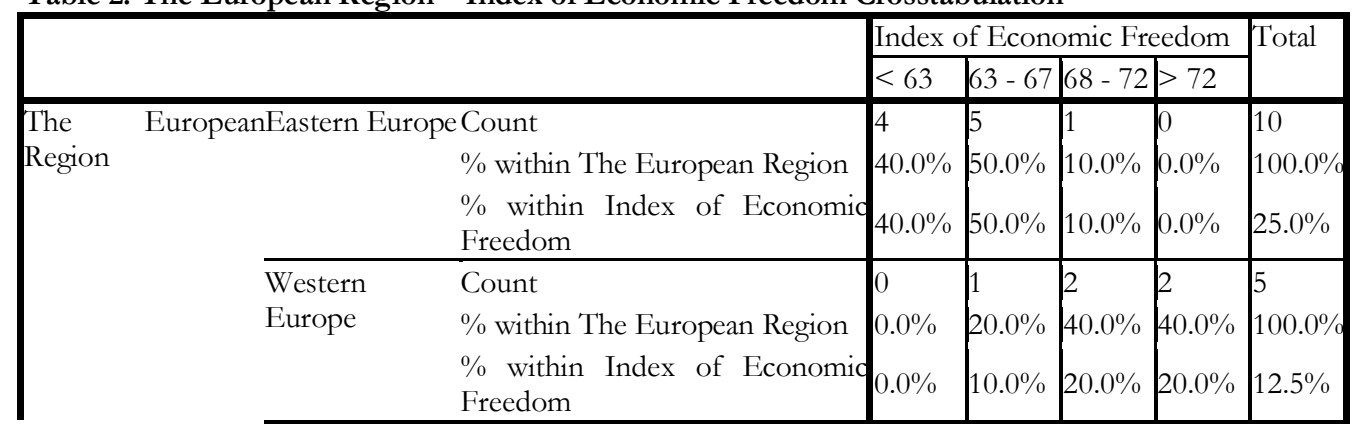




\begin{tabular}{|c|c|c|c|c|c|c|c|}
\hline & $\begin{array}{l}\text { Northern } \\
\text { Europe }\end{array}$ & $\begin{array}{l}\text { Count } \\
\% \text { within The European Region } \\
\% \text { within Index of Economic } \\
\text { Freedom }\end{array}$ & $\begin{array}{l}0.0 \% \\
0.0 \%\end{array}$ & $\begin{array}{l}0.0 \% \\
0.0 \%\end{array}$ & $\begin{array}{l}3 \\
30.0 \% \\
30.0 \%\end{array}$ & $\begin{array}{l}7 \\
70.0 \% \\
70.0 \%\end{array}$ & $\begin{array}{l}10 \\
100.0 \% \\
25.0 \%\end{array}$ \\
\hline & $\begin{array}{l}\text { South } \\
\text { Europe }\end{array}$ & $\begin{array}{l}\text { ofCount } \\
\% \text { within The European Region } \\
\% \text { within Index of Economic } \\
\text { Freedom }\end{array}$ & $\begin{array}{l}6 \\
40.0 \% \\
60.0 \%\end{array}$ & $\begin{array}{l}4 \\
26.7 \% \\
40.0 \%\end{array}$ & $\begin{array}{l}4 \\
26.7 \% \\
40.0 \%\end{array}$ & $\begin{array}{l}1 \\
6.7 \% \\
10.0 \%\end{array}$ & $\begin{array}{l}15 \\
100.0 \% \\
37.5 \%\end{array}$ \\
\hline Total & & $\begin{array}{l}\text { Count } \\
\% \text { within The European Region } \\
\% \text { within Index of Economic } \\
\text { Freedom }\end{array}$ & $\begin{array}{l}10 \\
25.0 \% \\
100.0 \%\end{array}$ & $\begin{array}{l}10 \\
25.0 \% \\
100.0 \%\end{array}$ & $\begin{array}{l}10 \\
25.0 \% \\
100.0 \%\end{array}$ & $\begin{array}{l}10 \\
25.0 \% \\
100.0 \%\end{array}$ & $\begin{array}{l}40 \\
100.0 \% \\
100.0 \%\end{array}$ \\
\hline
\end{tabular}

$40 \%$ of countries in Southern Europe have an economic freedom index score of less than 63 (Table 2). On the other hand, $70 \%$ of the states that have a score greater than 72 belong to Northern Europe (Fig 1). For Southern and Eastern Europe the graphs show that most countries have scores of social progress index lower than 78 . However, none of these regions has a score above 84 for this index. On the other hand, in the countries of Northern and Western Europe, most of them show higher values than the 84 for this index. In these regions there is no country that has a corresponding value of this index lower than 86.

Fig.1. The distribution of the sample by "Region" and "Index of Social Progress"

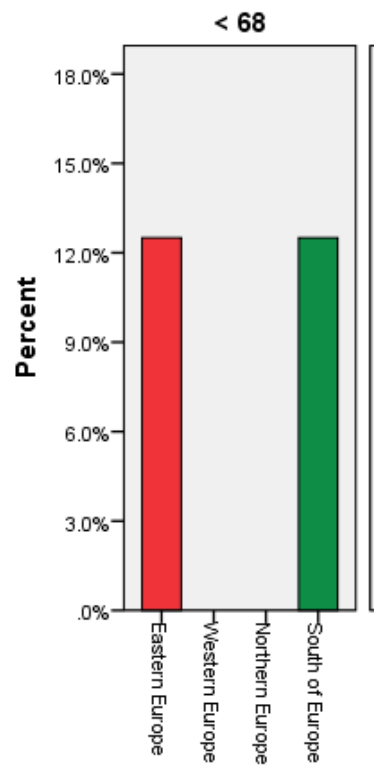

\section{Index of Social Progress}

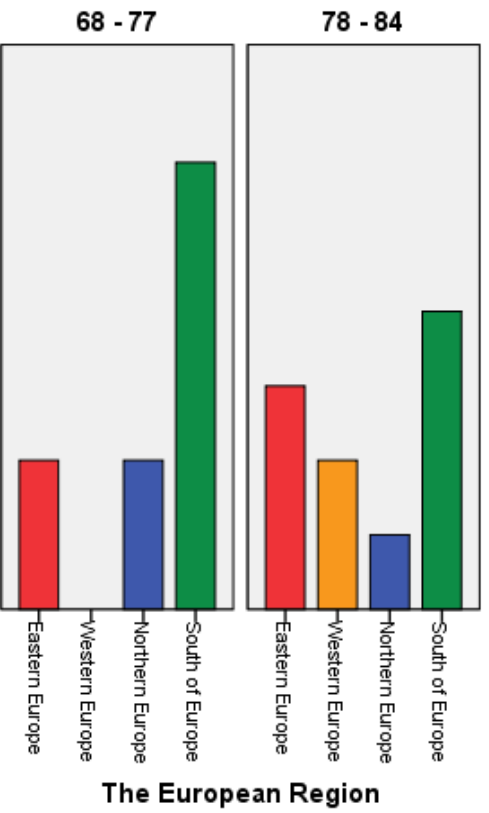

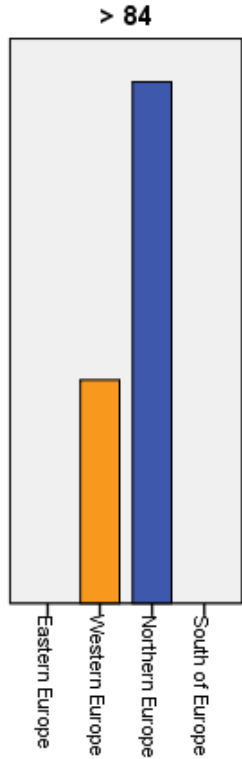

Among the countries with a score lower than 63 for economic freedom index, 40\% belong to Eastern Europe and are not EU member states, and 60\% belong to the Southern Europe. Among the countries in Southern Europe, 57\% are members of the EU. Regarding the countries with a score of economic freedom index greater than 72 , mostly are from Northern Europe (70\%) and members of the European Union (87.5\%). 
Using analysis of variance we we aim to find out if variable Membership of the European Union affects GDP per capita. In order to apply ANOVA, homogeneity of variance was tested using Levene's test. The conclusion is that ANOVA can be applied.

Table 3. ANOVA

GDP per inhabitant (2014)

\begin{tabular}{|l|l|l|l|l|l|}
\hline & Sum of Squares & df & Mean Square & F & Sig. \\
\hline Between Groups & 2636459284.818 & 1 & 2636459284.818 & 5.290 & .027 \\
Within Groups & 18937539532.679 & 38 & 498356303.492 & & \\
Total & 21573998817.496 & 39 & & & \\
\hline
\end{tabular}

There are significant differences between the average GDP per capita by membership. Therefore, variable Membership of the European Union significantly influence GDP per capita (Table 3).

Table 4. Correlations

\begin{tabular}{|ll|l|l|l|}
\hline & & $\begin{array}{l}\text { GDP per } \\
\text { inhabitant } \\
(2014)\end{array}$ & $\begin{array}{l}\text { Index of } \\
\text { Economic } \\
\text { Freedom }\end{array}$ & $\begin{array}{l}\text { Index of Social } \\
\text { Progress }\end{array}$ \\
\hline GDP per inhabitant (2014) & $\begin{array}{l}\text { Pearson Correlation } \\
\text { Sig. (2-tailed) }\end{array}$ & 1 & $.551^{* *}$ & $.845^{* *}$ \\
& $\mathrm{~N}$ & 40 & .000 & .000 \\
\hline Index of Economic Freedom & Pearson Correlation & $.551^{* *}$ & 1 & 40 \\
\hline & Sig. (2-tailed) & .000 & 40 & $.672^{* *}$ \\
& $\mathrm{~N}$ & 40 & .000 \\
\hline Index of Social Progress & Pearson Correlation & $.845^{* *}$ & $.672^{* *}$ & 1 \\
& Sig. (2-tailed) & .000 & .000 & 40 \\
\hline $\mathrm{N}$ & 40 & 40 & 40 \\
\hline
\end{tabular}

**. Correlation is significant at the 0.01 level (2-tailed).

There is a direct correlation between the economic freedom index and GDP per capita and between economic freedom index and index of social progress (Table 5). It may refer to a strong correlation between GDP per capita and social progress index. All these correlations are significant.

In order to model the economic growth on the base on economic freedom index and index of social progress for European countries we conducted a multiple regression model.

We conducted the regression model to study the influence of independent variables (economic freedom index and the index of social progress) on the dependent variable (the rate of growth of GDP per capita) for the European Union countries.

\section{Table 5. Model Summary}

\begin{tabular}{|c|c|c|c|c|c|}
\hline \multirow[t]{2}{*}{ Model } & \multicolumn{2}{|l|}{$\mathrm{R}$} & \multirow[b]{2}{*}{ R Square } & \multirow[b]{2}{*}{$\begin{array}{l}\text { Adjusted R } \\
\text { Square }\end{array}$} & \multirow[b]{2}{*}{$\begin{array}{l}\text { Std. Error of the } \\
\text { Estimate }\end{array}$} \\
\hline & $\begin{array}{l}\text { Membership of the } \\
\text { European Union }=\text { Yes } \\
\text { (Selected) }\end{array}$ & $\begin{array}{l}\text { Membership of } \\
\text { European Union } \sim=\text { Yes } \\
\text { (Unselected) }\end{array}$ & & & \\
\hline 1 & $.502^{\mathrm{a}}$ & .472 & .252 & .187 & 2.51274 \\
\hline
\end{tabular}

a. Predictors: (Constant), Index of Social Progress, Index of Economic Freedom

b. Unless noted otherwise, statistics are based only on cases for which Membership of the European Union $=Y$ Yes.

c. Dependent V ariable: Rate of Growth of GDP per inhabitant 
The value of the correlation coefficient of 0.502 means that there is a linear connection between variables and the environment. In addition, the value of the $\mathrm{R}$ Square $(0,252)$ represents $25.2 \%$ of the variation of the dependent variable that is explained by the independent variables included in the model, the difference to $100 \%$ being due to random factors not included in the model (Table 6).

Table 6. Regression Coefficients

\begin{tabular}{|c|c|c|c|c|c|c|c|}
\hline \multirow[t]{2}{*}{ Model } & \multicolumn{2}{|c|}{$\begin{array}{l}\text { Unstandardized } \\
\text { Coefficients }\end{array}$} & \multirow{2}{*}{\begin{tabular}{|l|}
$\begin{array}{l}\text { Standardized } \\
\text { Coefficients }\end{array}$ \\
Beta \\
\end{tabular}} & & \multirow[t]{2}{*}{ Sig. } & \multicolumn{2}{|c|}{$\begin{array}{l}\text { Collinearity } \\
\text { Statistics }\end{array}$} \\
\hline & $\mathrm{B}$ & Std. Error & & & & Tolerance & VIF \\
\hline 1(Constant) & -1.949 & 7.618 & & .256 & .800 & & \\
\hline $\begin{array}{l}\text { Index of Economic } \\
\text { Freedom }\end{array}$ & 321 & .116 & .636 & 2.769 & .011 & .615 & 1.625 \\
\hline Index of Social Progress & -.227 & 116 & -.448 & 1.948 & .064 & .615 & 1.625 \\
\hline
\end{tabular}

a. Dependent Variable: Rate of Growth of GDP per inbabitant

b. Selecting only cases for which Membership of the European Union $=$ Yes

The regression equation is:

$$
y=b_{0}+b_{1} \cdot x_{1}+b_{2} \cdot x_{2}=>y=-1.949+0.321 \cdot x_{1}-0.227 \cdot x_{2}
$$

For an assumed risk of 5\% the constant in the model is not statistically significant. The other parameters are significant and will be kept in the model. We will resume analysis without including constant. The value of the correlation ratio increased, therefore, there is a stronger relationship between the variables (Table 7).

Table 7. Model Summary

\begin{tabular}{|c|c|c|c|c|c|}
\hline \multirow[t]{2}{*}{ Model } & $\mathrm{R}$ & & \multirow[b]{2}{*}{ R Squareb } & \multirow[b]{2}{*}{$\begin{array}{l}\text { Adjusted R } \\
\text { Square }\end{array}$} & \multirow[b]{2}{*}{$\begin{array}{l}\text { Std. Error of the } \\
\text { Estimate }\end{array}$} \\
\hline & $\begin{array}{l}\text { Membership of the } \\
\text { European Union = Yes } \\
\text { (Selected) }\end{array}$ & $\begin{array}{l}\text { Membership of the } \\
\text { European Union } \sim=\text { Yes } \\
\text { (Unselected) }\end{array}$ & & & \\
\hline 1 & $.720^{a}$ & 1.000 & .519 & .479 & 2.46333 \\
\hline
\end{tabular}

a. Predictors: Index of Social Progress, Index of Economic Freedom

b. For regression through the origin (the no-intercept model), $R$ Square measures the proportion of the variability in the dependent variable about the origin explained by regression. This CANNOT be compared to $\mathrm{R}$ Square for models which include an intercept.

c. Unless noted otherwise, statistics are based only on cases for which Membership of the European Union $=Y$ es.

d. Dependent Variable: Rate of Growth of GDP per inhabitant

e. Linear Regression through the Origin

Tabelul 8. Regression coefficients

\begin{tabular}{|c|c|c|c|c|c|c|c|}
\hline \multirow[t]{2}{*}{ Model } & \multicolumn{2}{|c|}{$\begin{array}{l}\text { Unstandardized } \\
\text { Coefficients }\end{array}$} & \begin{tabular}{|l} 
Standardized \\
Coefficients
\end{tabular} & \multirow[t]{2}{*}{$t$} & & \multicolumn{2}{|c|}{ Collinearity Statistics } \\
\hline & $B$ & Std. Error & Beta & & & Tolerance & VIF \\
\hline $\begin{array}{l}\text { 1Index of Economic } \\
\text { Freedom }\end{array}$ & .312 & .109 & & & & .004 & \\
\hline $\begin{array}{l}\text { Index of Social } \\
\text { Progress }\end{array}$ & -.244 & .094 & -5.701 & 2.596 & .010 & .004 & 240.578 \\
\hline
\end{tabular}

a. Dependent V ariable: Rate of Growth of GDP per inhabitant 


\section{b. Linear Regression through the Origin}

c. Selecting only cases for which Membership of the European Union $=$ Yes

The regression equation is:

$$
\mathrm{y}=\mathrm{b}_{1} \cdot \mathrm{x}_{1}+\mathrm{b}_{2} \cdot \mathrm{x}_{2}=>\mathrm{y}=0.312 \cdot \mathrm{x}_{1}-0.244 \cdot \mathrm{x}_{2}
$$

For an increase by a point in the index of economic freedom, the growth rate of GDP per capita increases, on average, by $\$ 0.312$ in EU Member States when it is considered constant influence of other variables. For an increase by a point in the index of social progress, the growth rate of GDP per capita decreases, on average, by $\$ 0.244$ in Member States UE. The parameters are statistically significant as sig's values are lower than the risk $\alpha$ of 0.05 . Therefore, the growth rate of GDP is influenced by economic freedom and social progress for the Member States of the European Union.

\section{Conclusions}

Economic growth is a complex process targeting the economic system as a whole and in its dynamics. Economic growth highlights those changes occurring in the increase of the macroeconomic results expressed not independently, but in close connection with its determinants.

This study aimed at analysing economic growth in relation to the index of economic freedom and social progress index. After a preliminary analysis of the distributions of variables for the 40 countries considered in our sample, we conclude that the Southern and Eastern Europe countries present lower scores compared to the countries in other regions. Thus, many of the Southern and Eastern states have scores lower than 63 for the index of economic freedom and lower than 78 in terms of social progress index.

Most of these countries are post-communist states and, up to a point, their delay in terms of freedom and development can be explained by their past. Beyond this, it is a matter of reforms implemented while building the market economy.

Countries' membership to the European Union plays an important role in the evolution of the analysed indices. Thus, the states which have an index of economic freedom higher than 75 and belonging to the Northern Europe also belong to the European Union. Regarding social progress index, we find values higher than 84 for the EU member states.

The results of the analysis of variance show that there are significant differences between the averages of GDP per capita according to membership to European Union, this status significantly influencing the GDP.

Correlating the three analysed numeric variables we found that there is a positive medium relation between the index of economic freedom and GDP per capita and also between the index of economic freedom and the social progress index. At the same time, there is a strong positive correlation between GDP per capita and social progress index. Considering GDP growth rate as dependent variable and the index of economic freedom and social progress index as independent variables the analysis shows a positive medium relation between these variables. However, only 25,2\% of the variation of GDP growth rate is explained by the independent variables included in the model, the difference up to 
$100 \%$ being due to random factors not included in the model. However, our estimated model is validated both deterministic and stochastic.

In terms of the direction of GDP growth rate, we aimed at testing if it is influenced by the values of the two indices considered in the analysis. To determine this, we estimated a logistic regression model. However, the variables included in the model were not statistically significant. Thus, the two indices do not influence the direction of the GDP per capita growth rate, this one being influenced by other factors not included in our model.

\section{References}

Barro, R.J. (1997). Determinants of Economic Growth. A Cross-Country Empirical Study. Cambridge: MIT Press.

Baumol, W.J. (2002). The Free-Market Innovation Machine: Analyzing the Growth Miracle of Capitalism, Princeton: Princeton University Press.

Bjornskov, C.\&Foss, N.J. (2008). Economic freedom and entrepreneurial activity: Some cross-country evidence, Public Choice, 134 (3-4), p. 307-328.

Carlsson, F. \& Lundstrom, S. (2001). Economic Freedom and Growth: Decomposing the Effects, Working Paper in Economics, no.33, Department of Economics Göteborg University. Retrieved from http://swopec.hhs.se/gunwpe/papers/gunwpe0033.pdf

Engle, R. (2006). The Transition Countries of the European Union: An Assessment of Economic Progress and its Relation to the Index of Economic Freedom, Proceedings of the Conference on Trends in Global Business no. 1.

Farr, W.K., Lord, R.A. \& Wolfenbarger, J.L. (1998). Economic freedom, political freedom, and economic well-being: a causality analysis. Cato Journal, 18(2), 247-262.

Faria, H.J. \& Montesinos, H.M. (2009. Does Economic Freedom Cause Prosperity? An IV Approach. Public Choice, 141 (1-2), 103-127.

Feldman, H. (2007). Economic Freedom and Unemployment around the World. Southern Economic Journal, 74 (1), 158-176.

Gwartney, J.D., Lawson, R.A. \& Holcombe, R.G. (1999). Economic freedom and the environment for economic growth. Journal of Institutional and Theoretical Economics, 155(4), 643-663.

Hall, J.C. \& Lawson, R.A. (2014). Economic Freedom of the World: An Accounting of the Literature. Contemporary Economic Policy, 32(1), 1-19.

Heritage Foundation (2016). Index of Economic Freedom. Retrieved from

http://www.heritage.org/index/about

Iacobuță, A.O.\& Gagea, M. (2010). Institutional quality, economic freedom and sustainable development. A comparative analysis of EU countries. Revista Economică, 3 (20), 252-260.

Kacprzyk, A. (2016). Economic freedom-growth nexus in European Union countries. Applied Economics Letters, 23(7), 494-497.

Mușetescu, A. (2012). Importanța Indicelui Libertății Economice în caracterizarea mediului economic al unei țări, Revista Română de Statistică Trim. I, Supplement, 276-281.

Social Progress Imperative (2013). Social Progress Index 2013, eds. M.E. Porter, S. Stern \& R. Artavia Loría. Retrieved from

https://www2.deloitte.com/content/dam/Deloitte/se/Images/promo images/artiklar/The social progres s Index chapter2.pdf

Social Progress Imperative (2015). Social Progress Index 2013, eds. M.E. Porter, S. Stern \& M.Green. Retrieved from

https://www2.deloitte.com/content/dam/Deloitte/global/Documents/About-Deloitte/gx-cr-socialprogress-index-executive-summary-2015.pdf 